\title{
Legal and piscicultural-technological decisions for fish-farming use of natural water bodies
}

\author{
Nina Golovina ${ }^{1,2}{ }^{*}$ Sergey Kupinski ${ }^{1}$, Elena Danilova ${ }^{1,2}$ and Pavel Golovin ${ }^{1,2}$ \\ ${ }^{1}$ Dmitrov Fish Farming Industrial Institute (Branch), FSBEI “Astrakhan State Technical University" \\ ${ }^{2}$ Branch on Freshwater Fisheries FSBSI "All-Russian Institute of Fisheries and Oceanography" \\ («VNIIPRKh»), Moscow area, Dmitrov region, p. Rybnoe, 141821, Russia
}

\begin{abstract}
For fishery assessment of up-to-date state of three water storage reservoirs in the northern part of the Moscow area, classical methods of hydrobiological and ichthyological investigations were used, as well as echolocation and fish-farming plane-tables for calculation of growth possibilities of fish communities representatives. The low depths (average between 2 and $2.5 \mathrm{~m}$ ) of the Yakhromskoe and Velevskoe water storage reservoirs create favorable conditions for intensive development of aquatic plants, they show greater similarities of ichthyofauna but the low growth rate, of the bream (Abramis brama) as the main object at the amateurish fishing. The Zhestylevskoe water storage reservoir, having the greatest area and depth (average $6 \mathrm{~m}$ depth) and the weed filling less than 5\%, shows the bream growth rate higher than that one of the 2 other water bodies. The normative-legal rules of the Russian Federation permit to register officially fish cultural and fishing areas at water storage reservoirs of more than 100 hectare what allows to determine ways of their subsequent stable exploitation. On the example of the Yakhromskoe, Zhestylevskoe and Velevskoe water storage reservoirs, algorithms of reservoirs transference from one state into another one have been given with a view to use them intensively.
\end{abstract}

\section{Introduction}

The global stocks management in artificial water bodies is limited on the one hand by the lack of operative methodic approach to the assessment of their ecological potential, on the other hand by legal and normative documents which determine development of the fish fonds. The early conducted studies showed that a number of ecological factors as hydrological [1], temperature [2] regimes, eutrophication level [3] and others influence fish populations in water storage reservoirs.

Different methodics are offered to be used for assessment of a fish community state. The most significant of them are empiric models including common biomass assessment, predators and plankton-eater relationship [4,5], as well as acoustic systems and echosounding devices use [6] helping to find the concrete fish numbers.

Using these methods allowed to estimate the fishery potential of water storage

* Corresponding author: kafvba@mail.ru 
reservoirs in a number of European countries (France, Czech Republic, Poland) and to show its dependence on water bodies eutrophication levels $[4,6]$.

The global management of fish stocks in natural water bodies is directed on water bioresources protection and valuable commercial fish species stocking [3]. Moreover fish harvesting in many countries is carried out by fishermen-anglers because of commercial fishing lack [7-15].

For some years past, cardinal measures have been taken in the Russian Federation directed on subsequent development of the fishery complex. Grounds of its forming have been determined by the fishery complex development conceptions for the period up to 2030. The normative-legislative statements created conditions for stable extended use of inner water bodies, long-term leasing for organization of fishing places and fish farms. The order of making contracts for use of a fishing part was confirmed, and the procedure of a contract-making concerning use of a fishing place for industrial fishing in inner water bodies as well as organization of amateur and sport fishing was established. In water storage reservoirs (of more than 100 hectare area), fishing places are separated which could be officially registered with a long-term leasing aimed to carry out pasturable and industrial aquaculture.

Thus, perspectives of real fishery use of natural water bodies in the RF and possibilities of healthy fish production are enlarged.

One of the first steps to this direction seems to be evaluation of the ecological state of water objects as well as determination of possible conclusions for their further fishery use where commercial fishing is not carried out.

The objective of this study was to determine the common conception of the stable fish farming processes management and schemes of fish farming places exploitation at water storage reservoirs with different eutrophication levels.

\section{Materials and Methods}

As materials the data were taken on the state of water objects in the northern part of the Moscow area: the Zhestylevskoe, Yakhromskoe and Velevskoe water storage reservoirs, the information was collected in the period from 2013 to 2019. To estimate the level and dynamics of production processes the results of probes were used which were collected mainly in summer when these processes run most intensively. Hydrobiological probes of each water body were sampled at 5-7 stations. The abundance and biomass of phytoplankton and phytobentos, zooplankton and feed zoobenthos were determined by conventional hydrobiological methods.

The ichthyological material was sampled using throw net of $35 \mathrm{~m}$ common length and $2 \mathrm{~m}$ height. In sum, the morphobiological analysis was carried out for more than 3 tsd different fish species. By these data and some results of echolocation, the qualitative and quantitative composition of fish communities as well as the growth rate of mass fish species were estimated.

\section{Results}

\subsection{The Yakhromskoe water storage reservoir}

Is situated between three villages: Svistukha, Afanasovo and Kaporki, not far from the popular sports-touristic complex. It borders with the Moskva-river canal, its area is 127 hectare, the volume at the normal water head level is $2.95 \mathrm{mln} \mathrm{m} 3$. The depths in the water body increase gradually from the upper Yakhroma $(0.5 \mathrm{~m})$ to the dam $(4 \mathrm{~m})$. The middle 
depth is $2.5 \mathrm{~m}$. There are no gulfs, banks are high, covered mostly with forest. It is the littleflowing compact water body devided into separate places with tightly closed rough weeds.

Weed filling rate of the reservoir is estimated by $47 \%$ of its area where $43 \%$ are tightly closed weeds, and $44 \%$ is soft submerged vegetation. The heaviest weed filling is observed in the upper reservoir part, the least one is in the low part close to the dam.

The faunistic phytoplankton community of the observed reservoirs was represented mainly by diatoms and green algae where species pp. Cyclotella, Phacotus, Oocistis predominated. Total representatives of 39 genera have been revealed. The level of phytoplankton development in summer showed the next quantitative indices: biomass 2.3$3.6 \mathrm{mg} / \mathrm{l}$, numbers 1.2-3.0 mln specimen/l. As a whole this phytoplankton development indicates a high water body trophicity.

Zooplankton is represented by 22 species. Relatively low quantitative characteristics of zooplankton in the middle of summer (mean biomass $0.5-1.9 \mathrm{~g} / \mathrm{m} 3$ ) at the sufficient specific diversification indicates its eating-away and deficiency in feed organisms for fry and zooplankton-eating fishes.

Benthos is represented by chironomid larvae (Chironomidae fam.), ostracodes (subclass Ostracoda), roundworms (class Nematoda), mollusks (class Bivalvia and class Gastropoda). The most numerous mollusks species were clam coils, pond molluscs, toothless clams (freshwater clams). The highest species numbers and the maximum biomass of Gastropoda and Bivalvia were recorded in shallow-water parts where different species (pond clams, clam coils, pearl barley clam, Dreissena and others) inhabited in. The common biomass of benthos fluctuated between 7.7 and $16.0 \mathrm{~g} / \mathrm{m} 3$.

The fish community is represented by 25 species, calculated fish productivity was 30 $\mathrm{kg} / \mathrm{ha}$, and the possible catch between 9 and $10 \mathrm{~kg} / \mathrm{ha}$. The lack of the regular fishing and the irregular ecosystem development to the direction of the excessive development of the benthic phytocenosis resulted in forming excellent conditions in reservoir for phytophilous fishes spawning and for their excess. The result of which is unsufficiency of fishes feeding and their growth. The mass of fishes of the same age (bream, roach) is 4 to 5 times lower than that one of appropriate species on the average for the RF water bodies. The substantial fish part is weakened and affected by metacercaria of trematodes genus Postodiplostomum (fig. 1). The well visible signs of this lesion (black spots on the body surface) deteriorate production quality of fish and lead to decrease of amateur fishing.

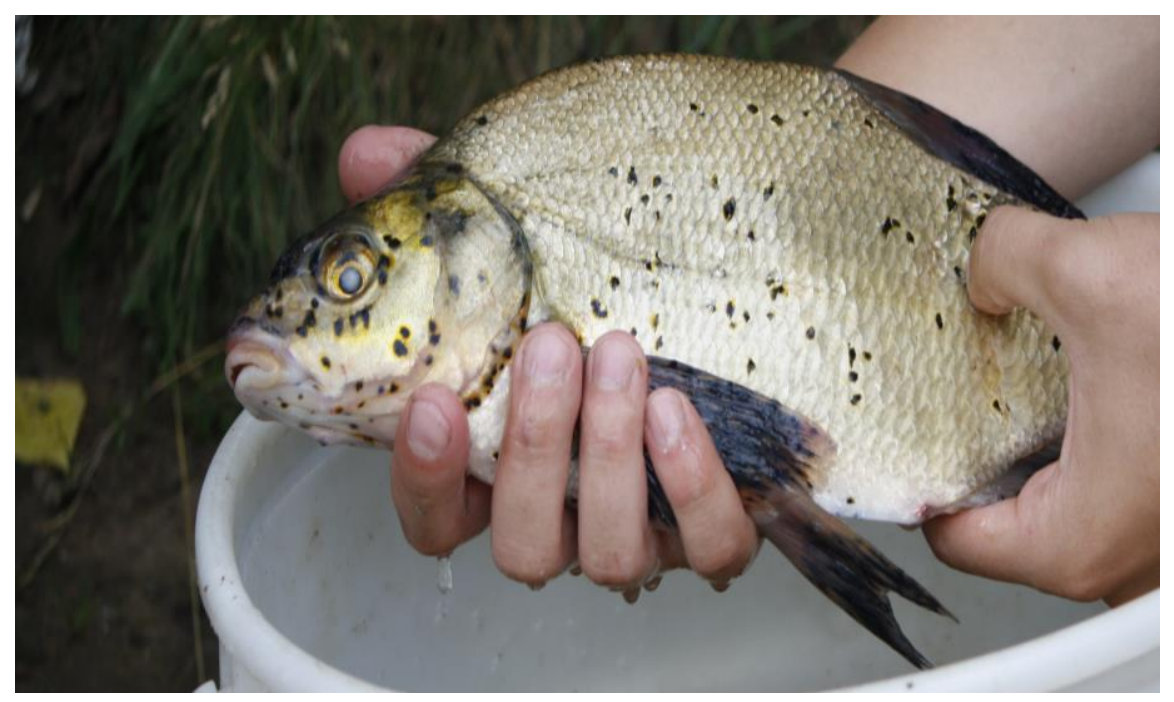

Fig. 1. Postodiplostomosis in bream. 


\subsection{The Zhestylevskoe water storage reservoir}

It is situated $10 \mathrm{~km}$ from the city Dmitrov. Its area is 166 hectare, extended along the Yakot and Vozha river-bed. The reservoir has a number of narrow, deep falling into it bays. The depths increase gradually, from the upper reaches of rivers $(1.5-2 \mathrm{~m})$ to the dam (the maximum depths in the dam part at the full water volume is between 12 and $14 \mathrm{~m}$ ). The reservoir is a low-running water body with the narrow line of riverside shoals occupied with higher aquatic vegetation (mainly Eleocharis palustris). The overgrowing level is slack (less than $5 \%$ of the area).

It should be observed that in the central and adjoining to the dam reservoirs parts, there were poor diversification of phytoplankton (18 genera), relatively low of zooplankton (14 species) at the sufficiently high its numbers and biomass $(544.5 \mathrm{sp} / \mathrm{m} 3$ and $2.7 \mathrm{~g} / \mathrm{m} 3$, respectively), poor specific diversification of zoobenthos ( 7 species) and the relatively good biomass (34.2 g/m2), not high specific diversification of fishes (14 species). There are no signs of postodiplostomosis in fish. The fish productivity level of the reservoir is between 50 and $53 \mathrm{~kg} / \mathrm{ha}$, and the possible catch could be between 16 and $20 \mathrm{~kg} / \mathrm{ha}$.

The water reservoir was given to the Branch of the Freshwater Fisheries FSBSI "VNIRO" ("VNIIPRKh") for long-term leasing and is used as a head pond and accumulation reservoir for the experimental-productional section of the "VNIIPRKh". It is available for recreational and amateur fishing.

\subsection{The Velevskoe water storage reservoir}

It is situated in the Dmitrov region near the village Novoe Seltso and formed as a result of the Velya-river regulating. It was constructed for needs of agriculture (irrigation of agricultural areas and as a cattle-pond). Presently, it has the status mainly as the recreational water body, and possesses a strongly marked river-bed course. Its characteristics are the following: 128 ha area, $3500 \mathrm{~m}$ length, $290 \mathrm{~m}$ maximum width. The depths of this reservoir, increase gradually from the upper reaches to the dam. The maximum depth is $6 \mathrm{~m}$, the middle depths is $2 \mathrm{~m}$. The transparency is up to $1 \mathrm{~m}$. The visible flowing of water could be noted (up to $0.3 \mathrm{~m} / \mathrm{sec}$ ).

The level of weed filling is not high (11\% of the area, mainly in the upper part), the character of the overgrowing is not regular and insular.

The reservoir is characterized by the highest indices of phytoplankton $(14.55 \mathrm{mg} / \mathrm{l})$ and zooplankton $(4.92 \mathrm{~g} / \mathrm{m} 3)$ biomass as well as by a relatively low development of the feed zoobenthos $(6.6 \mathrm{~g} / \mathrm{m} 2)$ in comparison with other water bodies studied. There are 18 species in the fish community. The calculated fish productivity is about $90 \mathrm{~kg} / \mathrm{ha}$, the possible catch is between 45.5 and $55.5 \mathrm{~kg} / \mathrm{ha}$. A nidus of postodiplostomosis is noted.

The data of echolocation show sufficient numbers of low-sized fishes. In combination with well-developed plant communities in the upper reservoir part, it is an indication of a sufficient volume of phytophilous young fish as the results of yearly spawning show.

\section{Discussion}

On the whole, processes of hydrobionts fauna forming in reservoirs studied depend closely on hydrological peculiarities of water bodies what provides production of a certain biocenosis. Thus, low depths of the Yakhromskoe and Velevskoe reservoirs (average 2$2.5 \mathrm{~m}$ ) create favorable conditions for intensive development of aquatic plants. The reservoirs show great similarities of ichthyofauna, but low growth rate of bream as the main object of amateurish fishing. The Zhestylevskoe reservoir has the larger area and depths(average $6 \mathrm{~m}$ ), weed filling is less than $5 \%$, the bream growth rate is higher there than 
in two other water bodies.

In the Zhestylevskoe and Velevskoe reservoirs, a high infestation rate in bream, roach and bleak by postodiplostomides metacercaria was noted what is the sign of postodiplostomosis nidi development in these water bodies. Low depths, high weed filling level by higher aquatic plants, euthrophication of these reservoirs are favorable conditions for gastropods mollusks development, which are intermediate hosts, as well as presence of fish-eating birds (herons, gulls) as definitive hosts of Postodiplostomum. This disease is not noticed in the Zhestylevskoe reservoir.

Fish communities of the reservoirs observed are presented by 25, 14, 18 species in the Yakhromskoe, Zhestylevskoe, Velevskoe water bodies, respectively. On the whole, there are 27 fish and fish-shaped species (table) including three representatives of species which entry into the Red book of the Moscow area (Lampetra planeri, Abramis sapa, Cottus gobio).

The closest specific similarity (16 common species) is observed between the Yakhromskoe and Velevskoe reservoirs. The predominant objects of the amateur fishing in the tree reservoirs are 2 species (roach and bream).

Table 1. Specific composition of fish population of the reservoirs observed.

\begin{tabular}{|c|c|c|c|c|}
\hline Families & Specieses & $\begin{array}{c}\text { The } \\
\text { Yakhromskoe } \\
\text { reservoir }\end{array}$ & $\begin{array}{c}\text { The } \\
\text { Zhestylevs- } \\
\text { koe reservoir }\end{array}$ & $\begin{array}{c}\text { The } \\
\text { Velevskoe } \\
\text { reservoir }\end{array}$ \\
\hline $\begin{array}{l}\text { Petromyzontid } \\
\text { ae }\end{array}$ & $\begin{array}{l}\text { Lampetra planeri (Bloch, } \\
1784 \text { ) }\end{array}$ & + & & \\
\hline Esocidae & Esox lucius Linnaeus, 1758 & + & + & + \\
\hline \multirow{2}{*}{ Cyprinidae } & $\begin{array}{l}\text { Abramis brama (Linnaeus, } \\
1758 \text { ) }\end{array}$ & + & + & + \\
\hline & $\begin{array}{ll}\text { (Abramis } & \text { sapa } \\
\text { Pallas, 1814) } & \end{array}$ & + & & \\
\hline \multirow{12}{*}{ Cyprinidae } & $\begin{array}{ll}\text { Alburnus } & \text { alburnus } \\
\text { (Linnaeus, 1758) }\end{array}$ & + & + & + \\
\hline & $\begin{array}{l}\text { Aspius aspius (Linnaeus, } \\
1758)\end{array}$ & + & & \\
\hline & $\begin{array}{l}\text { Blicca bjoerkna (Linnaeus, } \\
1758 \text { ) }\end{array}$ & + & & + \\
\hline & $\begin{array}{ll}\text { Carassius } & \text { auratus } \\
\text { (Linnaeus, 1758) } & \end{array}$ & + & + & + \\
\hline & $\begin{array}{ll}\text { Carassius } & \text { carassius } \\
\text { (Linnaeus, 1758) } & \end{array}$ & + & + & \\
\hline & $\begin{array}{l}\text { Cyprinus carpio Linnaeus, } \\
1758\end{array}$ & & & + \\
\hline & $\begin{array}{lll}\text { Gobio } & \text { gobio } & \text { (Linnaeus, } \\
1758) & & \end{array}$ & + & + & + \\
\hline & $\begin{array}{ll}\begin{array}{l}\text { Leucaspius } \\
\text { (Heckel, 1843) }\end{array} & \text { delineatus } \\
\end{array}$ & + & + & + \\
\hline & $\begin{array}{ll}\text { Leuciscus } & \text { cephalus } \\
\text { (Linnaeus, 1758) } & \end{array}$ & + & & + \\
\hline & $\begin{array}{l}\text { Leuciscus idus (Linnaeus, } \\
1758 \text { ) }\end{array}$ & + & & + \\
\hline & $\begin{array}{ll}\text { Rhodeus } & \text { sericeus } \\
\text { (Pallas, 1776) }\end{array}$ & + & & \\
\hline & $\begin{array}{l}\text { Rutilus rutilus (Linnaeus, } \\
1758 \text { ) }\end{array}$ & + & + & + \\
\hline
\end{tabular}




\begin{tabular}{|c|c|c|c|c|}
\hline & $\begin{array}{l}\text { Scardinius } \\
\text { erythrophthalmus } \\
\text { (Linnaeus, 1758) }\end{array}$ & & & + \\
\hline & $\begin{array}{c}\text { Tinca tinca } \\
1758)\end{array}$ & + & & + \\
\hline Cobitidae & $\begin{array}{ll}\begin{array}{l}\text { Misqurnus } \\
\text { (Linnaeus, 1758) }\end{array} & \text { fossilis } \\
\end{array}$ & + & + & + \\
\hline & $\begin{array}{l}\text { Cobitis taenia Linnaeus, } \\
1758\end{array}$ & + & + & \\
\hline & $\begin{array}{l}\text { Perca fluviatilis Linnaeus, } \\
1758\end{array}$ & + & + & + \\
\hline Percidae & $\begin{array}{l}\text { Gymnocephalus cernuиs } \\
\text { (Linnaeus, 1758) }\end{array}$ & + & + & + \\
\hline & $\begin{array}{l}\text { Sander lucioperca } \\
\text { (Linnaeus, 1758) }\end{array}$ & + & & \\
\hline Balitoridae & $\begin{array}{l}\text { Barbatula barbatula } \\
\text { (Linnaeus, 1758) }\end{array}$ & + & + & + \\
\hline Lotidae & Lota lota (Linnaeus, 1758) & + & & + \\
\hline Eleotrididae & $\begin{array}{ll}\text { Perccottus } & \text { glenii } \\
\text { Dybowski, } 1877 & \end{array}$ & + & + & \\
\hline Cottidae & $\begin{array}{l}\text { Cottus gobio Linnaeus, } \\
1758\end{array}$ & + & & \\
\hline Total & 27 & 25 & 14 & 18 \\
\hline
\end{tabular}

The comprehensive hydrobiological and ichthyological studies of the three reservoirs showing different eutrophication levels, allow to estimate perspectives of their further practicable fishery use for the purpose of obtaining healthy fish production.

To realize fish-farming-technological solutions of the effective pisciculture use it is necessary first of all to confirm their legal status and to register the long-term leasing for exploitation as fish farming places.

The common conception for the sustainable management of fish farming processes in the Yakhromskoe reservoir as a recreational one is possible by piscicultural-technological from of the pasturable intensive fish culture:

- regular fishing and immediate catch of some local fish groups with the heaviest lesion by postodiplostomosis and their utilization into the healthy production;

- grass carp introduction into the reservoir in order to control higher aquatic plants;

- black carp introduction into the reservoir for mollusks number decrease and for postodiplostomosis nidus elimination;

- adjusting system of information collection on recreational fishermen numbers, volume and structure of their catches;

- organization of ecological tourism groups and their education, e.i. cognitive use of the water body.

The measures recommended on improving fishery use of the Zhestylevskoe reservoir as a recreational one are connected with the economic activities of "VNIIPRKh" which took this water body on long-term lease.

They are:

- to carry out a detailed echo shooting of the reservoir to estimate fish groups numbers and distribution of different size, species and ages with the purpose of revealing potentional objects for selective fishing (first of all numbers of large-sized planktophages - silver carps);

- to provide conditions for effective spawning of phytophilic fishes, including artificial spawning places use;

- to carry out a purposeful dosing fertilization of the water body with a view of increasing 
its total productivity with the parallel introduction of cultures highly productive protococcal algae;

- to carry out works on precise calculation of fishermen numbers as well as on volume of aquatic bioresources caught by them;

- to consider a possibility of predatory fish (zander) introduction into the reservoir for decrease and further control of slow-growing fish species (Rutilus rutilus, Leucaspius delineates, Alburnus alburnus) quantity;

- the organize commercial fish rearing in cages.

The immediate recommended measures on improving fishery use of the Velevskoe reservoir are the following:

- to carry out a detailed echolocation of the water body to estimate numbers and distribution of fish groups of different species and ages as well as to reveal potential objects for commercial fishing (large-sized ones) and to determine a possible volume of feed resources for potential predators introduced (pike, zander);

- to consider a possibility of black carp introduction for decrease mollusks and reduction of fish invasibility by postodiplostomes;

- to carry out works on precise calculation of fishermen numbers as well as on volume of aquatic bioresources caught by them.

Based on results of measures, carried out for the Velevskoe reservoir, the long-term leasing is possible with organization at the water body pasturable, recreational and probably industrial (cage) fish culture.

\section{Conclusions}

1. Fishery use of natural water bodies is based on the realization of legislative and piscicultural and technological decisions including cyclic recurrence and effectivity.

2. Presently, the most regulated water bodies are those which are taken on long-tern lease in accordance with the contract for water use and realization of the business program on conversion them into a new state being exploited for purposes of fishculture (pasturable, or industrial ones).

3. For the Yakhromskoe reservoir, it would be in perspective the organization of an intensive pasturable fish cultural farm with the recreational and ecological direction. It is possible to keep pasturable fish farming with a cage system mounted for commercial fish rearing at the Velevskoe and Zhestylevskoe reservoirs.

\section{References}

1. A.P. Eloranta, A.G. Finstad, I.P. Helland, O. Ugedal, M. Power, Science of The Total Environment 618, 313-322 (2018) doi.org/10.1016/j.scitotenv.2017.10.268

2. J. Jonathan, M.A. Spurgeon, K.L. Pegg, Lin Xiea Pope, Ecological Indicators 112, 106130 (2020) doi.org/10.1016/j.ecolind.2020.106130

3. P. Blabolil, M. Logez, D. Ricard and others, Fisheries Research 173(1), 80-87 (2016) doi.org/10.1016/j.fishres.2015.05.022

4. A.W. Tranmer Dana, W. Clelia, L. Marti, D. Vidergar, R. Benjankar, D. Tonina, P. Goodwin, J. Imberger, Journal of Environmental Management 260, 110107 (2020) doi.org/10.1016/j.jenvman.2020.110107

5. R. Lyach, M. Čech, Fisheries Research 201, 131-137 (2018) doi.org/10.1016/j.fishres.2018.01.020

6. L. den Heuvel, M. Blicharska, S. Blyth, P. Rönnbäc, Fisheries Research 223, 105444 
(2020) doi.org/10.1016/j.fishres.2019.105444

7. J.W. Brownscombe, K. Hyder, W. Potts, K.L. Wilson, K.L. Pope, A.J. Danylchuk, S.J. Cooke, A. Clarke, R. Arlinghaus, J.R. Post, Fisheries Research 211, 247-255 (2019) doi.org/10.1016/j.fishres.2018.10.019

8. J. Curtis, B. Breen, P.O'Reilly, C. O'Donoghue, Water Resources and Rural Development 10, 14-21 (2017) doi.org/10.1016/j.wrr.2017.11.001

9. S. Burgin, Sustainability 9(2), 280 (2017) doi.org/10.3390/su9020280

10. E. Stokstad, $Q \& A$ (2019) www.sciencemag.org/news/2019/03/qa-why-fisherymanagers-need-overhaul-recreational-fishing-rules, doi:10.1126/science.aax4047

11. N.W.R. Lapointe, S.J. Cooke, J.G. Imhof and others, Environmental Reviews: NRC Research Press 22(2), 110-134 (2014) doi: 10.1139/er-2013-0038

12. A.M. Villamagna, B. Mogollón, P. Angermeier, Ecological indicators 45, 255-265 (2014) doi: 10.1016/j.ecolind.2014.04.001

13. M. Young, S. Foale, D. Bellwood, Marine Policy 66, 114-123 (2016) doi: https://doi.org/10.1016/j.marpol.2016.01.018

14. C. Polizzi, M. Simonetto, A. Barausse and others, Ecosystem Services 14, 158-169 (2015) doi: https://doi.org/10.1016/j.ecoser.2015.01.001

15. R. Arlinghaus, J. Abbott, E. Fenichel, S. Carpenter, L. Hunt, J. Alós, T. Klefoth, S. Cooke, R. Hilborn, O. Jensen, M. Wilberg, J. Post, M. Manfredo, PNAS 116(12), 5209-5213 (2019) https://doi.org/10.1073/pnas.1902796116 